\title{
ISLAM AND MODERNITY: REMEMBERING THE CONTRIBUTION OF MUHAMMAD 'ABDUH (1849-1905)
}

\author{
Aasia Yusuf*
}

\begin{abstract}
The Egyptian jurist, religious scholar, and reformer, Muhammad 'Abduh (d. 1905), is regarded as the architect of what has become known in the West as 'Islamic modernism'. A disciple of Jamāl al-Dīn Asadābādī - better known as 'al-Afghānī' (d. 1897) - 'Abduh's intellectual legacy opposes despotism and champions freedom, law, and rationality. One of the major aims of 'Abduh was to show that Islam is reconcilable with modern thought, and thus, he argued that Islam is indeed compatible with the supposed requirements of the modern mind. He not only stressed that Islam taught the acceptance of all the products of reason and intellect, but also asserted the need to interpret and reapply the principles and ideals of Islam to formulate new responses to the political, scientific and civilisational challenges of the west and of modern life. This article discusses 'Abduh's contribution and his legacy within this context. It also throws light on Muhammad 'Alī Pasha's (r. 1805-48) preceding policy of modernisation in nineteenth-century Egypt (including education and social and political reforms) and on 'Abduh's role in reforming Cairo's Al-Azhar University.
\end{abstract}

\section{Introduction}

The history of Islamic modernism and Islamic renewal (tajdìd) in Egypt is the upshot of the 'encounter' between the Egyptian way of life and western civilisation in the nineteenth and twentieth century. This encounter, in fact, brought about changes in the social, political and cultural life of the Egyptian people, which in turn generated tension in the minds of the Muslim intelligentsia. On the religious plane, this resulted in the division of the 'ulamá' into two camps: one favouring change in response to the western challenges and the other adopting a totally antagonistic attitude toward everything which the west presented. In response to this scenario, thinkers like alAfghān̄ and 'Abduh emerged as a force which generated the issue of change and renewal (tajdìd) within the context of Islamic civilisation.

This article maintains that these thinkers argue that Islam is reconcilable with modern thought and ideas that it are indeed compatible with supposed requirements

* Aasia Yusuf is a PhD research scholar in the Department of Islamic Studies, Aligarh Muslim University, Aligarh, India. She would like to thank Dr Christoph Marcinkowski (Co-Chair of Publications, IAIS Malaysia) for putting her contribution into shape for publication. 
of modern minds. It also discusses the prevailing conditions of Egypt during the nineteenth and early twentieth century, making out the two Muslim intellectuals Jamāl al-Dīn Asadābādī ('al-Afghānī') and Muḥammad 'Abduh as the towering figures of that period. The article also takes into account the modernisation measures in Egypt that took place after the expulsion of the armies of Revolutionary France ${ }^{1}$ and the coming to power of Muhammad 'Alī Pasha. It also discusses the impact of al-Afghānī on 'Abduh and throws light on the contribution of the latter to reform Cairo's Al-Azhar University. 'Abduh, being an ardent advocate of Islamic renewal and a believer in the harmony between reason and revelation, advocated legal and theological reform and called for universal education.

\section{Muḥammad 'Alī Pasha and his Reforms}

After the French were expelled, Muhammad 'Alī Pasha (r. 1805-1841) came to power. ${ }^{2} \mathrm{He}$ was an Albanian officer who is often referred to as the "founder of modern Egypt' because of the dramatic reforms in the military economic and cultural spheres that he instituted. Moreover, he established the dynasty that held power until the revolution of 1952. The 'ulamä' had incited the people to demonstrate in the streets against the Ottoman governor (wālī) and make Muhammad 'Alī governor of Egypt instead on the condition that he rule with their consultation. ${ }^{3}$ The 'ulama' ' of Al-Azhar had helped him to power, but he soon curbed their political influence and economic autonomy. The Egyptians of that time encountered the West from a position of a great material weakness and Egypt had entered a period of severe decline. Local despotisms flourished in the Arab lands at large and the economy sank to subsistence levels. Egypt's new energetic ruler strove to transform a backward country of a vast population into a state powerful enough to counter further assaults from Europe and also to maintain its de facto independence from the Ottomans in Istanbul.

Muhammad 'Alī launched Egypt's first industrialisation effort, borrowing both models and techniques from the West. In 1811, he involved the Egyptians in five wars which stretched over the period between 1811 and 1828. The political and military structures established by Muhammad 'Alī were designed to serve the objectives of his reformist modernisation programme and to extend his dynasty's power. Later on, the regime actively encouraged the cultivation of cotton, and the increasing exports of this product made the economy dependent on the international market. He also reformed and modernised the civil bureaucracy. European experts worked in Egypt and Egyptian students were sent to Europe to study. ${ }^{4}$

Muhammad 'Alī might have felt that in order to strengthen his rule he had to modernise the country. For this he needed to raise money. In order to do so he introduced certain reforms. Through his land reforms, for instance, he dealt 
a severe blow at the holdings of the multazims [...]. In 1814, he completely abolished the iltizam system [...]. Muhammad 'Alī, however, did not abolish the feudal state as a whole, not for an individual lord... Moreover, it was not long before most of the land which had passed under the control of state was once again in private hands [...]. Muhammad 'Ali distributed large tracts of land to his kin and members of his suite, to higher dignitaries and officers of the Albanian, Kurdish, Circassian and Turkish detachments [...]. Thus having deprived the ancient feudal nobility of its estates and power and having liquidated the multazim class, Muhammad 'Alī created in its place a new feudal nobility which became the mainstay of the new dynasty. ${ }^{5}$

After accomplishing his land reforms, Muhammad 'Alī turned his attention to the military sector. He created a native army of Egyptian fallāhīn - Arab peasants, farmers, or agricultural labourers - who were trained by European military experts, mainly French and Italians. A remarkable name in this regard was the talented French officer, Joseph Anthelme Sève (1788-1860), who became known after his conversion to Islam as 'Sulaymān Pasha'. The modernisation of the army led to the development of ordnance factories. Smelting shops, metal workshops and sail-canvas manufactories were built at the Alexandria shipyard. An iron foundry with an annual capacity of 2,000 tons of pig iron, three arsenals along French lines, saltpetre works and a gunpowder factory were also built. Cotton, linen, fez, cloth mills and sugar factories appeared. ${ }^{6}$

Similarly, there took place considerable developments in the field of agriculture, especially rice and cash crops such as cotton and indigo, etc. The growth of cotton was facilitated by the introduction of a new cotton plant by the Frenchman, Jumel. Moreover, Muhammad 'Alī embarked on extensive irrigation projects. His great achievement in this regard was the establishment of a big barrage on the Nile. These measures were responsible for bringing enormous areas of land under cultivation. ${ }^{7}$

Muhammad 'Alī's reformist measures were achieved at the cost of the people. His great desire to build up a formidable army started a chain of modernising processes in almost every sphere of life. His Europeanising zeal needed a new bureaucracy which in turn called for a "new educational" system instead of the traditional one. Many young Egyptians belonging to the elite class were sent to Europe to study military science, technology, medicine, agriculture, and languages, etc. It was these people who upon their return home from abroad assumed various administrative and executive posts in the government and became officers and engineers at various states enterprises. At the beginning of Muhammad 'Alī's reign, there was only one system of education, that is, the traditional and religious and inherited from the past. However, over the years there began a tradition of secular education which was a new thing in the history of Muslim Egypt. The new educational system consisted of three stages: primary, secondary and tertiary, followed by a four-year specialisation. 
Apart from this, Muhammad 'Alī established various institutions for polytechnic and engineering and agriculture. He also established a school for linguistics as well as a musical school. Moreover, he founded modern hospitals for soldiers and civilians. These measures were quite unheard of by most of Egyptians of the time. Another important step taken by Muhammad 'Alī Pasha, which played an important role in the cultural renaissance of Egypt, was the establishment of its first printing press in 1882, which published books in Arabic, Persian, and Ottoman-Turkish. The first Egyptian newspaper, al-Waqa' $i{ }^{\prime}$ al-mișriyyah (Egyptian events), appeared from this press.

Muḥammad 'Alī Pasha sent also scholars, doctors, engineers abroad for training for the newly established schools as well as translators for modern technical terms. These were the people who comprised his educational mission sent to Europe, especially the Italian states and France. The travelling Egyptians were directly exposed to Western manifold influences. When they returned to their country, they became instrumental in modernising Egyptian society. Efforts were made to translate scientific and technical works in Arabic.

Muhammad 'Alī's other projects included the extension of the irrigation system, the promotion of cotton as a cash crop for export, the centralisation of the taxation system, and the establishing of monopolies in industry and foreign trade. Western advisors helped him to build a modern army and to train officers, administrators, and technicians. This new army enabled Muhammad 'Alī to conquer parts of the Arabian Peninsula, the Sudan, and Greece (in the name of the Sultan). However, when he rebelled in the 1830s against his suzerain in Istanbul and seized Palestine and Syria, the European powers forced him back to his Egyptian base and made him pare down his army. Nevertheless, he obtained from the Sultan the hereditary governorship of Egypt. ${ }^{8}$

\section{Al-Afghānī and His Impact on Muhammad 'Abduh}

Jamāl al-Dīn Asadābādī - better known as 'al-Afghānī' (d. 1897) the famous writer, 'pan- Islamist' political activist and modernist - was one of the most influential figures in the Muslim world in the nineteenth century. His books and articles also confirm the influence of rationalist Islamic philosophers and thinkers like Ibn Sīnā (the 'Avicenna' of the Latin Middle Ages, d. 1037) and Nașīr al-Dīn Țūsī (d. 1274). ${ }^{9}$ Al-Afghānī was the first modern Muslim figure to be involved in a wide variety of activist political undertakings. His intelligence and personality quickly brought him into high circles - those of the Ottoman Tanzimat reformers then in power. He was involved in the Ottoman council of education and Istanbul's new university, where he gave a series of public lectures. In the 1870s, Al-Afghānī lived in Cairo and spent most of this time in teaching, introducing an interpreting Islamic philosophy that included restricting rational inquiry to the elite while encouraging orthodoxy among 
the masses. As Egypt entered a political and financial crisis in the late 1870s, AlAfghānī encouraged his disciples to publish political news articles; he gave speeches and carried out political activities as head of a secret society. His followers included several young men who later became the leaders of Egyptian political and intellectual life, notably, his closest disciple, the young Muhammad 'Abduh and others.

When al-Afghānī went to India - then under British colonial rule - he wrote a series of articles, his most famous treatise was known in English under the title "The Refutation of the Materialists." Al-Afghānī also wrote an article which was published in the Journal des debats, constituting his famous answer to the French philosopher and writer Ernest Renan (d. 1892) in which he appeared with a sceptical view about religion, as did Renan, with whom he, however, disagreed in saying that Islam and Arabs were no worse than others. ${ }^{10}$ Al-Afghān̄'s thorough and well documented grounding in Islamic philosophy -in texts allowed him to give his modernising thought an Islamic base.

When he was in Paris, he was joined by Muhammad 'Abduh. Together they organised a secret society of Muslims, aiming at working for the unity and reform of Islam. The extent of the society is obscure, although it is known to have had branches in Tunis and elsewhere. Under its auspices the two of them published, eighteen issues of an Arabic periodical - al- 'Urwah al-wuthqa (The Firmest Rope), which took its title from a qur'ānic phrase ${ }^{11}$ and whose main themes were 'pan-Islamist' and antiBritish. It was devoted partly to an analysis of the policies of the great powers in the Muslim world, particularly exposing the inner weakness of Islam and exhorting Muslims to overcome it. The language of the periodical was 'Abduh's while the thought was of al-Afghānī's. Both for its content and its language, it became one of the most influential of Arabic periodicals. ${ }^{12}$

Muhammad 'Abduh, aside from al-Afghānī the other great Muslim reformer, was born in Northern Egypt and received a traditional Islamic education in Tanta during the reign of Muhammad 'Alī Pasha. In 1877, he graduated from Al-Azhar University in Cairo where he taught for the next two years. During that period he met al-Afghānī whose influence upon 'Abduh's thought over the next decade would be profound. When al-Afghānī was expelled from Egypt in 1879, 'Abduh was also briefly exiled from Cairo to his native village. After returning from there, he became the editor of the official government gazette, the already referred to $a l-W a q \bar{a}^{\prime} i{ }^{\prime} a l$ mișriyyah $^{13}$ and began to publish articles on the need to reform in the country. Due to the British occupation of Egypt, which resulted in the 'Urābi 'revolt' of 1882, 'Abduh was sentenced to three years in exile for assisting the nationalists. After his return to Cairo, his thoughts and efforts were drawn towards the education and renewal (tajdīd) of Islamic theology. His training in the familiar scholastic patterns of tafsìr (qur'ānic exegesis) and fiqh (Islamic jurisprudence) had made him aware of the impediment to critical self-awareness. His ideas found some continuing expression through the 
pages of the influential journal al-Manār (The Lighthouse), aside from the alreadymentioned and short-lived, but highly influential journal al- 'Urwah al-wuthqā.

'Abduh began a rapid ascent in the Egyptian judicial and political circles. Beginning as a judge in the Egyptian government, 'Abduh became a member of the newly established administrative board for Al-Azhar University in 1895 and also appointed member of the legislative council an advisory body serving at the behest of the khedive, Egypt's ruler. In the same year he became the grand mufti or the chief Islamic jurist of Egypt. As the head of Egypt's religious law courts, 'Abduh championed reforms that he saw necessary to make the sharì'ah relevant.

The most celebrated theological work of Muhammad 'Abduh is his Risālah altawhìd (Treatise on the Unity of God), in which he attempted - perhaps for the first time in the modern history of Islam - to construct a kind of systematised and humanist theology consistent with modern concepts. In this book he tried to reformulate the fundamental positions of Islam in not too technical terms as far as possible. It contains the theological lectures given by him in Beirut ${ }^{14}$ and deals with the Unity of God, the foundation of morals, prophethood, the Qur'ān, and the religion of Islam in general. Although having tried in this work to reconstruct Islamic theology in light of modern Western liberal thought, 'Abduh did not make any significant attempt to break away from orthodox Islam, and his definition of tawhīd signifies his attitude in this respect.

\section{'Abduh's Role in Reforming Al-Azhar University}

'Abduh believed that in order to bring about reform and the renewal of Egypt, it was not possible to do so without a change in the teaching methods at Al-Azhar, the introduction of new sciences and a return to the classical texts. His ideas soon gathered momentum in the form of the reform movement led by him and his associates. As he thought, the higher education of Muslims was the most significant problem to which he devoted himself. His attempts at reforming their education, on the one hand, and the reform of Islamic doctrines, on the other, form two aspects of the same activity. It was only by raising the general level of the education of Muslims that the corrupting influences which permeated Muslim life could be exposed and uprooted. ${ }^{15}$ It was therefore quite logical that he would concentrate on the reform of the centre of Muslim higher education, i.e. Al-Azhar University, as he thought that if Al-Azhar was reformed, it would set the tone for Muslim education everywhere.

There is no doubt that there was a time when the Azhar University had been a flourishing centre of learning. However, when the glory of Islamic learning and scholarship began to fade -around the twelfth and thirteenth centuries - Al-Azhar too lost much of its vitality and was reduced to a position in which it could hardly play any role in the regeneration of Muslim society. The syllabi were reduced to a sterile repetition of scholastic medieval dogma. The traditional sciences - based on divine 
revelation and, therefore exempt from any criticism - became finally established as the basis of Azharite study. The chief traditional sciences were theology, jurisprudence, hadith and Sufism. The rational sciences which included philosophy, rhetoric, logic, and astronomy, were relegated to the background and subordinated to the traditional sciences. For instance, the purpose of the study of astronomy became restricted to the finding out of the times for prayer or of the beginning of the lunar months, whereas the study of arithmetic became limited to the elementary technique of apportioning an inheritance ${ }^{16}$ In this regard, the twentieth-century Muslim Egyptian scholar and writer, Aḥmad Amīn (1886-1954), asserted that "a student in al-Azhar ended his studies by understanding a few works on theology, but so far as secular learning was concerned, he remained completely ignorant. There was no question of teaching geography, history, physics, chemistry, etc., for the Azharites looked down upon them as worldly sciences." 17

With the arrival of al-Afghānī in Egypt in 1876 the reform movement in the country received a new impetus. The liberal section of Al-Azhar soon gathered around him. There developed a strong opinion inside as well as outside Al-Azhar expressing dissatisfaction with the prevalent education system in Al-Azhar and desiring change. However, the most serious attempts to change Al-Azhar should be credited to Muhammad 'Abduh who tried to make the reform of the institution the main task of his life's work. He dreamed of Al-Azhar as a place where the young Egyptians should imbibe "western learning and science" along with the knowledge of "classical Islam and its glorious past." 18

Thus, the great contribution of 'Abduh can be traced to the fact that he was successful in opening the doors of Al-Azhar to the new cultural influence and liberal tendencies. The names of Muștafā 'Abd al-Rāziq (1885-1947, the Grand Imam of AlAzhar), Qāsim Amīn (1863-1908, an Egyptian jurist and one of the founders of the Egyptian national movement and Cairo University), 'Alī 'Abd al-Rāziq (1888-1966, an Egyptian Islamic scholar and sharī' ah judge), Aḥmad Amīn, Țāhā Ḥusayn (18891973, often nicknamed the 'Dean of Arabic Literature', one of the most influential twentieth-century Egyptian writers and intellectuals, and a figurehead for the 'Arab Renaissance' (al-Nahdah) and the modernist movement in the Arab World) and Khālid Muhammad Khālid (1920-96, Egyptian political and religious thinker and writer), to name a few, may be mentioned among those whose ideas, nourished in the liberal tradition of Muhammad 'Abduh, found roots in Al-Azhar, and laid the foundation of what may be called the Abduh school.

\section{'Abduh as the Architect of Islamic Renewal}

As we have seen, the crucial influence in 'Abduh's development was the impact of al-Afghānī, who emphasised the concept of ummah (the Muslim community) against 
the concept of nationalism. 'Pan-Islamism' was al-Afghānī's response to British rule in Egypt and elsewhere and to European colonialism in general.

'Abduh affected a balance between Islam and modernity. However, one wonders whether this balance was not more illusory than real. In 'Abduh's view, the conflict between religion and science arose from the rigidity which afflicted all spheres of the Muslim community. He argued that once this rigidity disappears - and disappear it must- then they will find the Qur'ân waiting for them, preparing the means of salvation and supporting them through it with a holy spirit and providing them with the spiritual sources of science.

Underlying 'Abduh's programme was also the elimination of disunity within the ummah and alleviating the spiritual crisis contingent on its failure to apply fully the law of Islam. Modern condition, having brought about foreign institutions in economic, educational, political and social matters, drew the ummah gradually, but irresistibly away from traditional and $\operatorname{shari~}^{\mathrm{T}} a h$ precepts. ${ }^{\mathrm{c}} \mathrm{Abduh}$, as a disciple of al-Afghānī, embraced a position that was similar to that of his teacher, although 'Abduh's approach was less rationalist because he was influenced less by philosophy and more by traditional Islamic learning. The cornerstone of 'Abduh's thought was the idea that the changes that had occurred in the Muslim world were irreversible and that more changes were likely on the way. Therefore, his main concern was the preservation of ethics and morality in Muslim society. To achieve this goal, 'Abduh concluded that it must be demonstrated that the changes that had taken place were not only permitted by Islam, but were, indeed, its necessary implications if it were rightly understood. Further, he urged that, this approach did not mean that religious leaders should legitimise everything that was done in the name of change and modernisation. On the contrary, he saw Islam as a principle of constraint that would enable Muslims to distinguish between what was good and what was bad among all the suggested direction of change. Methodologically, 'Abduh criticised taqlìd, the practice of imitating earlier ulama, and instead emphasised ijtihād and reliance on fundamental sources - Qur'ān and Sunnah. ${ }^{19}$

By the mid-nineteenth century, however, the terms tajdìd (renewal) and ișlāh (reform) acquired the added meaning of reform in the sense of reconciling Islam with rationalist and scientific thinking and restructuring the educational and socio-political institutions of Muslim countries more or less along the lines of European institutions. The Indian Muslim reformer, Sir Sayyid Aḥmad Khān's (d. 1898) movement, especially his educational reforms, was also close to this conception of reform. Ișläh in this sense is primarily associated with 'Abduh and his disciples. 'Abduh is viewed, at least in the Arab world, as the founder of the Islamic modernist school of thought. ${ }^{20}$

Al-Afghānī and 'Abduh argued that Islam is not a hindrance to scientific and other progress, and they worked hard to validate their views. They advocated reforms for the restoration of Islam's rationalist and scientific spirit and the interpretation of its 
basic tenets in ways more suited to the current conditions and needs of Muslims. They have rightly been recognised as the originators of a new conception of reforms in Islam. 'Abduh is generally considered to be the father of Islamic modernism, while alAfghānī is indisputably the most ardent promoter of Islamic unity as a necessary element in any Islamic intellectual, economic, and political revival. ${ }^{21}$ As Muslim modernists and thinkers, they enforced to encourage the intellectual and scientific revitalisation of Muslim societies. Al-Afghānī stressed the point that Islam and science were not only compatible, but that, of all religions, Islam was the friendliest to science.

In addition, 'Abduh was convinced that Muslim nations could not become stronger and prosperous again until they acquired from Europe the sciences which were the product of its activity of mind, and they could do this without abandoning Islam, for Islam taught the acceptance of all the products of reason. This involved a change in the institutions of Islamic society: its legal system, its school, and its methods of government. ${ }^{22}$ 'Abduh initiated a movement which was aimed at reforming the whole of Egyptian society. He ardently desired to make his people accept the new prospects which the West was presenting and change their mental attitude. Like Sir Sayyid Ahmad Khān, he was much interested in social reform and fully realised that the progress of his people depended on sensible acceptance of the new Western values. Both these two Muslim modernists had one significant difference in their attitude: Sir Sayyid Ahmad Khan, who, intensely impressed by the West, was in favour of borrowing the values of the latter unquestioningly, so that his opponents labelled him in Urdu as necharī (followers of Nature/naturalist). In comparison, 'Abduh was more tied down to the traditional forms.

'Abduh had not only to make great endeavours, but also to prepare his community to accept new ideas. He launched a strong movement against orthodox trends and the medieval frame of mind and asked "the gentry 'ulama" who by virtue of their position are regarded as the 'spirit' of the ummah to accept the new prospects which the West was presenting, especially through its secular sciences.

'Abduh was much impressed by the striking contrast between the two civilisationsthe one flourishing and the other decaying. He eagerly studied the causes which led to the growth of Western civilisation. It was thus after his return to his country from his first visit to Europe that he soon became absorbed in the manifold activities of social reform and public welfare. He was convinced, like Sir Sayyid Aḥmad Khān, that the task of social regeneration would be effectively accomplished through cooperation with the British authorities whose help he always sought.

\section{The Concept of Religious and Civilisational Renewal}

If 'Abduh evaded from opening old theological controversies, the reason for this was perhaps his immediate concern for the unity of the ummah and the realisation that the 
ummah had to be reformed in order to check the process of decline. The adoption of Western ideas and institutions, he felt, would not serve the desired goal of reform. However, the task of 'Abduh to initiate Islamic reformation was made difficult by the fact that the orthodoxy which had gained an upperhand since medieval times continued to exercise its influence and prevented all social or intellectual progress. Traditional concepts were made the mainstay of Islamic thought and beliefs. During the eighteenth and nineteenth centuries, when the Muslims came in direct contact with the West, they were suddenly confronted with a realisation of their utter backwardness and impotence in almost every aspect of life. This generated an intellectual crisis in the Muslim intelligentsia, producing in its wake a whole crop of apologists, revivalists and modernists. On the religious plane, the Muslim modernists like 'Abduh and al-Afghānī attempted to meet the challenge by restating Islam in the light of the contemporary situation.

The educated class and the intellectuals of Egypt, who had come into contact with the West, believed in the complete westernisation of society. Influenced by western science and learning, they generally became indifferent towards religion. 'Abduh strongly disfavoured these westernised Egyptians, for, to him, Islam was a valuable asset, as it was to other Muslim 'modernists'. His purpose was to show that an idealised Islam could provide the basis of a modern society; at the same time he was bitterly hostile to the idea that what was done in the West should be approved ipso facto by Muslim society. On the contrary, he considered Islam as a potent factor in life. ${ }^{23}$ The task of raising the whole nation from a state of backwardness to a higher level of culture and civilisation, 'Abduh believed, was not merely a matter of imitating the secular West. It was his conviction that the programme of moral regenerations of his people must have its roots in the real and enduring values of religion. 'Religion', he claimed, was the prime teacher, the best guide of human souls, the greatest educator in calculating in the people the qualities of justice, mercy and magnanimity.

It was one of 'Abduh's major purposes to show that Islam can be reconciled with modern thought. He argued that Islam was compatible with the supposed requirements of the modern mind. He carried farther a process seen at work in the light of personalities like Rifā'ah Rafi` al-Ṭahțāwī (d. 1873, an Egyptian writer, teacher, translator, Egyptologist and renaissance intellectual, and among the first Egyptian scholars to write about Western cultures in an attempt to bring about a reconciliation and an understanding between Islamic and Christian civilisations), Khayr al-Dīn Pasha al-Tūnisī (a Tunisian political reformer during a period of growing European ascendancy, a former Prime Minister of Tunisia and subsequently Grand Vizier of the Ottoman Empire, d. 1890), and al-Afghānī: that of identifying certain traditional concepts of Islamic thought with the dominant ideas of modern Europe. In this line of thought mașlahah (public interest) gradually turns into utility, shürāa (consultation) into parliamentary democracy, $i j m \bar{a}^{\prime}$ (consensus) into public opinion - Islam itself becomes 
identical with civilisation and activity, the norms of nineteenth-century social thought. ${ }^{24}$

The key to his defence of Islam - indeed to all his thought about it - was a certain conception of true religion: a distinction between what was essential and unchanging in it and what was inessential and could be changed without damage. The real Islam, he maintained, had a simple doctrinal structure, it consisted of certain beliefs about the greatest question of human life and certain general principles of human conduct. To enable us to reach these beliefs and embody them in our lives both reason and revelation are essential. They neither possess a separate sphere nor conflict with each other in the same sphere.

The purpose of religious reform, according to 'Abduh, was to utilise the confidence of a Muslim that he has in his religion so as to turn it into an important instrument of change and progress of his people.

\section{Ijtihäd and Taqlīd, Reason and Science}

With the formation of the four 'schools' of Sunni jurisprudence, the historical beginnings of taqli d (imitation) coincide. The decisions given were codified into an unalterable corpus juris of lasting value defying change. Henceforth, the gate of $i j t i h \bar{a} d$, i.e. independent legal reasoning, was declared closed by most of the Muslim theologians and for about a thousand years the religious life of Muslim were regulated by taqli $\bar{d}$, i.e. 'the adoption of the utterances or actions of another as authoritative with faith in their correctness without investigating his reasons'. The 'consensus', attained at in the second and third centuries of Islamic history led to the stagnation of intellect and the promulgation of new ideas was more or less forbidden. The task of later scholars was confined to explaining and commenting on the decisions of early theologians.

Against this tendency to stifle independence of thought 'Abduh raised his strong voice. It is true that even in the earlier periods there were persons who had opposed the principle of taqli $d$ and claimed the right of $i j t i h \bar{a} d$. For example, Ibn Taymiyyah (d. 1328) and his disciple Ibn Qayyim al-Jawziyyah (d. 1350) were amongst those who condemned taqli $\bar{d}$ in its traditional form and paved the way for the modernist school of 'Abduh. 'Abduh too refused to bind himself to any codification of thought or to the decisions of the various 'schools'. However, the concept of ijtihäd as a theological technique assumed far-reaching significance in the hands of 'Abduh who interpreted the shari 'ah within the context of problems and needs of modern society.

Muslim modernists and the liberal Islamic thinkers initiated their reform movement when they saw the outlook of the society was constantly changing. They asserted that the altered conditions of life and the new intellectual tendencies made the abandonment of simple taqli $d$ and the reopening of the gate of $i j t i h \bar{a} d$ necessary; that the incompatibility of Islam with modern thought was due only to its wrappings of 
outworn medieval scholasticism, and that on the contrary Islam, rightly understood in its original form, was not only in full agreement with the assured results of scientific investigation, but was even in closer harmony with them than any other religious system. 'Abduh thus became the spearhead of the movement of rationalism and liberalism in Egypt. He had argued in his Risālah that

Islam declares openly that man was not created to be led by a halter, but by signs of universe and the indications of events - and that teachers are only those who arouse and direct and guide into the way of investigation $[\ldots] .{ }^{25}$

According to the traditionalists, the right to interpret Islamic scriptures belonged exclusively to the early generations of Muslim scholars. This negated the right of the later generation to interpret Islam in its own way. 'Abduh revolted against this exclusive attachment to the past and declared that precedence in time was no ground for preference. He stressed the right to individual freedom in matters of belief and in the interpretation of religion and declared that the privilege of a layman and nonexpert to interpret Islam according to his own understanding must not be suppressed.

It is obvious from the above mentioned views that 'Abduh recognised independence of thought for every Muslim, and allowed him to hold what his own reason derived from the Quran and the tradition.

In fact, any study of 'Abduh's rationalism must remain incomplete without reference to his attitude toward science. The Christian scholars and missionaries levelled the accusation against Islam that it was by its very nature hostile to science. However, 'Abduh claimed that the distinguishing trait of Islam was its rationality of the highest degree, and therefore, how could such a faith be incompatible to science? In fact, there could be no contradiction between Islam and science; on the contrary, he said, Islam was an ally of science and there was complete harmony between the two. Islam, he said, encouraged the study of natural phenomena to which there were many references in the Qur'ān. If rightly interpreted, science could be brought to conform to religion. In his commentary of the Qur'ān, 'Abduh tried to harmonise the new scientific discoveries of the modern age with the qur'ānic references to natural phenomena.

Muhammad 'Abduh, who fully realised the study of the science of the study of natural sciences, was disappointed to see that the 'ulama $\bar{a}$ ' and the people were apathetic towards the latter. He expressed surprise at this attitude of the 'ulama', for he considered that the sciences opposed by them were the same as had been cultivated by the Muslims for hundreds of years in the past. It was the Arabs who had translated the writings of the Greek scholars, had developed the sciences of agriculture and astronomy, had created algebra and chemistry, and provided in Europe a school of philosophy at Cordova and a school of medicine at Salerno. During the darkest period of European history and for 500 years the Muslims carried for all humanity the torch of knowledge. Thus, the Renaissance in Europe owed much to the Muslims who 
introduced scientific and technological knowledge to the Europeans. Thus, 'Abduh tried to convey to the minds of his indolent people that there was nothing to be feared from western sciences. On the contrary they should welcome these sciences to regain their heritage through the Europeans.

\section{Al-Afghānī, 'Abduh, and 'Pan-Islamism'}

Al-Afghānī is strongly associated with two movements: one is nationalism, with the support of Egypt and the other is 'pan-Islamism', which started with the later nineteenth-century Ottoman Sultans. In keeping with the view of anti-imperialism, he wanted the independence of Muslim countries on stressing pragmatic aspects of internal reform and self-improvement, including scientific and technical education. ${ }^{26}$

His chief disciple, Muhammad 'Abduh, even though he renounced al-Afghān̄̄'s political activism, carried on one aspect of one Afghani's work when he tried to elaborate modern and pragmatic interpretations of Islam. Among 'Abduh's disciples were Rashīd Riḍa and others, who wanted to go back to the ways of Prophet Muhammad's early followers.

In their attempt to have a universal Muslim union and to free Islamic states from foreign penetration and native tyranny, both al-Afghānī and 'Abduh urged the Muslims to reject their own local nationalisms which made them forgetful of the greater Islamic union. It was Islamic unity which they extolled over everything. They believed that the brotherhood of Islam obliterates racial and national boundaries and constitutes a bond which united all Muslims as one community. Thus, in one of his articles under the caption "Nationality (al-jinsiyyah) and the Religion of Islam," 'Abduh vigorously condemned the idea of racialism or nationalism. Nationalism or racialism, Abduh urged, is not a natural feeling based on human nature, but only an acquired state of feeling; and the Islamic feeling transcends the feelings of nationality. For he who belongs to the Faith of Islam. Once his belief is firmly entrenched, is diverted from his nationalism and racialism. Since Islam never recognised any 'așabiyyah (group feeling, social cohesion) except the religious one, Muslims throughout their history till today never gave up this bond of religious unity.

Thus, the religious feeling of solidarity is placed higher than national solidarity, and he reaffirms the idea that there was no room for nationalism in Islam. And further defending religious solidarity (al-ta'așsub al-dininyah), he argues that the condemnation of religious solidarity was, in fact, an imperialist intrigue to deprive the Muslims of their single bond of unity, viz., Islam. In its place the imperialists propagated nationalism only to do away with the foundation of an 'Islamic nation' (al-millat al-islämiyyah) and divide the latter on the basis of race, in order to bring to you their aggressive designs. The Muslims who accepted this did, in fact, destroy the religious bond (al- 'așābiyyah al-dīnīyyah) . 
Al-Afghānī called on his students, including 'Abduh, to workout interpretations of Islam along these lines. The call for unity al-Afghānī embodied was driven by his conviction that the entire Muslim world, not just its frontiers, lay vulnerable to the power of the West. Deliberately cultivating mystery around his origins and his movements, al-Afghānī's message resonated with particular force in Egypt. Al-Afghānī had not remained isolated from modern trends in science and social thought, despite its traditional methods. From the time of Muhammad 'Alī Pasha, Muslim students and scholars had been sent abroad to study western sciences. Al-Afghānī made himself a major, though controversial, intellectual force at Al-Azhar. Al-Azhar proved an important centre of resistance against the Western threat in the nineteenth century.

Although, national states have been in existence within the domain of Islam for many a century, yet Islamic law recognises the only one and indivisible ummah. ${ }^{27}$ Thus, the all-inclusive unit never existed anywhere as a reality, yet the ummah remained as an ideal in the minds of Muslims. 'Abduh, in the true Islamic spirit, regarded nationalism as a divisive factor which sought to destroy the idealised concept of unity and established a narrow framework for the universal Islam.

\section{Conclusions and Recommendations}

The above discussion reveals that Muhammad 'Abduh was a pioneer among those Muslims whose thoughts and ideas serve as a legacy to the present century on Islamic modernism. Witnessing the penetration of Western culture, 'Abduh, through his liberal and humanitarian interpretation of Islam, prepared the minds of Muslims in general and particularly of his Egyptian countrymen to accept modern science, rationalism, and reason, and give up the moribund tradition of the past.

- It thus becomes clear that his contribution as an Islamic modernist is so significant that a fresh insight study of his system of thought seems viable for an understanding of the development of the modern Islamic reform and renewal movement, not only in Egypt, but in the Muslim world in general.

- What also becomes clear is that Islam played a vital role in constantly shifting Egyptian public life towards development and progress. In Islamic history, prominent Islamic intellectuals like al-Afghānī and 'Abduh have formed and articulated unique and diverse responses to modernity and the influence of the West. This is best demonstrated by their creative attempts to mediate modernity as to appropriate and extend its influence in Egypt under Islamic terms.

- Lastly, 'Abduh's thought and intellectual contribution contends that there is no incompatibility between Islam and modernity. It allows for making changes in all fields, viz., education, science, progress and development, 
without damaging the true spirit of Islam, as Islam is a religion which is in complete harmony with reason and rational attitude of life.

\section{Notes}

1. On the Egyptian expedition of the French and its impact on Egypt, see Paul Strathern, Napoleon in Egypt (London: Vintage Books, 2008).

2. Still the best study on his reign is Afaf Lutfi Al-Sayyid Marsot, Egypt in the Reign of Muhammad Ali (Cambridge: Cambridge University Press, 1984).

3. Raymond Baker, "Egypt," in: John L. Esposito (ed.), The Oxford Encyclopaedia of the Modern Islamic world (New York: Oxford University Press, 1999), 1: 430 (Hereafter cited in its abbreviated form as $O E M I W)$.

4. Ibid.

5. V. Lutsky, The Modern History of the Arab Countries (Moscow: Central Books Ltd, 1969), 54.

6. Ibid.

7. Mahmudul Haq, Islam in Modern Egypt: The Nineteenth Century (Aligarh [India]: Moon Printing Press, 1988), 32.

8. Donald Malcolm Reid, "Muhammad Ali Dynasty," in: OEMIW, 3:166.

9. Nikki R. Keddie, "Afghani, Jamal al-Din," in: OEMIW, 1:23-27.

10. Albert Hourani, Arabic Thought in the Liberal Age (Oxford: Oxford University Press, 1970), 109.

11. Qur'ān 2:256.

12. Sohail H. Hashmi, "Abduh Muhammad," in: Richard C. Martin (ed.), Encyclopaedia of Islam and the Muslim World (New York: Macmillan, 2004), 1:6-7.

13. Ibid.

14. M. A. Zaki Badawi, The Reformers of Egypt (London: Croom Helm, 1978), 51.

15. H. A .R. Gibb, Modern Trends in Islam (Chicago: University of Chicago Press, 1954), 39.

16. Mahmudul Haq, A Study of Modern Thinkers of Egypt (Calcutta: Little Flower Press, 1970), 66.

17. Ibid.

18. Ibid.

19. Shireen T. Hunter, "Introduction," in: Shireen T. Hunter (ed.), Reformist Voices of Islam; Mediating Islam and Modernity (New Delhi: Pentagon Press, 2009), 15-16.

20. Ibid., 5 .

21. Ibid., 14-15.

22. Hourani, Arabic Thought, 151 .

23. Haq, A Study, 84.

24. Hourani, Arabic Thought, 144.

25. Haq, A Study, 88.

26. Keddie, "Afghani," 1:26.

27. R .N. Frye (ed.), Islamic Society and the West (The Hague: Mouton and Co., 1957), 8-9, as cited in Haq, A Study, 28. 